\title{
PIIISGUC.ORG
}

"iş, GÜÇ" ENDÜSTRi iLişKILERI VE INSAN KAYNAKLARI DERGISi

"IS, GUC" INDUSTRIAL RELATIONS AND HUMAN RESOURCES JOURNAL

\section{The Relationship Among Organizational Commitment and Organizational Citizenship Behavior -A Research Study On Call Center Employees}

\author{
Eda KILIÇ \\ PHD Student, Uludağ University, Institute of Social Sciences, Labor Economics and \\ Industrial Relations Programme
}

Temmuz/July 2013, Cilt/Vol: 15, Say1/Num: 3, Page: 83-93

ISSN: 1303-2860, DOI: 10.4026/1303-2860.2013.0233.x

Makalenin on-line kopyasına erişmek için / To reach the on-line copy of article:

http://www.isguc.org/index.php?p=article\&id=518\&cilt=15\&sayi $=3 \& y i l=2013$

Makale İçin İletişim/Correspondence to:

Eda Kılıç/ Email: edaakademik@gmail.com 


\title{
FIIISGUCORG 020002013 \\ "İş,Güç" Endüstri ilişkileri ve İnsan Kaynakları Dergisi "Işs,Güç" Industrial Relations and Human Resources Journal
}

\author{
Temmuz/July 2013, Cilt/Vol: 15, Say1/Num: 3, \\ Sayfa/Page: 83-93, DOI: 10.4026/1303-2860.2013.0233.x
}

"İş,Güç" Endüstri İlişkileri ve İnsan Kaynakları Dergisi, yılda dört kez yayınlanan hakemli, bilimsel elektronik dergidir. Çalışma hayatına ilişkin makalelere yer verilen derginin temel amact; belirlenen alanda akademik gelişime ve paylaşıma katkıda bulunmaktır.

"İş,Güç" Endüstri İlişkileri ve İnsan Kaynakları Dergisi'nde, 'Türkçe' ve 'İngilizce' olarak iki dilde makale yayınlanmaktadır. "İş, Güç" Endüstri İlişkileri ve İnsan Kaynakları Dergisi, ulusal ve uluslararası birçok indekste taranmaktadır. (Cabell's Directories, Ebsco Socindex, Index Islamicus, Index Copernicus International, Worldwide Political Science Abstracts, Sociological Abstract, Ulakbim Sosyal Bilimler Veritabanı, ASOS Index)

Editör / Editor in Chief

Aşkın Keser (Uludağ University)

\section{Editör Yardımcıları / Co-Editors}

Şenol Baştürk (Uludăg University)

K.Ahmet Sevimli (Uludağ University)

Gözde Yllmaz (Marmara University)

Uygulama / Design

Yusuf Budak (Kocaeli University)

Tarandiğı Indeksler / Indexes ASOS INDEX

CABELL'S DIRECTORIES

EBSCO SOCINDEX

Index ISLAMICUS

Index COPERNICUS Int.

Sociological Abstract

ULAKBİM Sosyal Bilimler

Veritanı

Worldwide Political Science

Abstracts

\author{
Yayın Kurulu / Editorial Board \\ Dr.Şenol Baştürk (Uludă̆ University) \\ Yrd.Doç.Dr.Zerrin Fırat (Uludă̆ University) \\ Doç.Dr.Aşkın Keser (Uludă̆ University) \\ Prof.Dr.Ahmet Selamoğlu (Kocaeli University) \\ Yrd.Doç.Dr.Ahmet Sevimli (Uludağ University) \\ Doç.Dr.Abdulkadir Şenkal (Kocaeli University) \\ Doç.Dr.Gözde Yılmaz (Marmara University) \\ Yrd.Doç.Dr.Memet Zencirkıran (Uludă̆ University)
}

Uluslararası Danışma Kurulu / International Advisory Board

Prof.Dr.Ronald Burke (York University - Kanada)

Assoc.Prof.Dr.Glenn Dawes (James Cook University - Avustralya)

Prof.Dr.Jan Dul (Erasmus University - Hollanda)

Prof.Dr.Alev Efendioğlu (University of San Francisco - ABD)

Prof.Dr.Adrian Furnham (University College London - Ingiltere)

Prof.Dr.Alan Geare (University of Otago - Yeni Zellanda)

Assoc. Prof. Dr. Diana Lipinskiene (Kaunos University - Litvanya)

Prof.Dr.George Manning (Northern Kentucky University - ABD)

Prof.Dr.Mustafa Özbilgin (Brunel University - UK)

Assoc. Prof. Owen Stanley (James Cook University - Avustralya)

Prof.Dr.Işık Urla Zeytinoğlu (McMaster University - Kanada)

Ulusal Danışma Kurulu / National Advisory Board

Prof.Dr.Yusuf Alper (Uludă̆ University)

Prof.Dr.Veysel Bozkurt (Ístanbul University)

Prof.Dr.Toker Dereli (Işık University)

Prof.Dr.Nihat Erdoğmuş (İstanbul Şehir University)

Prof.Dr.Ahmet Makal (Ankara University)

Prof.Dr.Süleyman Özdemir (İstanbul University)

Prof.Dr.Ahmet Selamoğlu (Kocaeli University)

Prof.Dr.Nadir Suğur (Anadolu University)

Prof.Dr.Nursel Telman (Maltepe University)

Prof.Dr.Cavide Uyargil (İstanbul University)

Prof.Dr.Engin Yildırım (Anayasa Mahkemesi)

Doç.Dr.Arzu Wasti (Sabancı University)

Dergide yayınlanan yazllardaki görüşler ve bu konudaki sorumluluk yazarlarına aittir.

Yayınlanan eserlerde yer alan tüm içerik kaynak gösterilmeden kullanılamaz.

All the opinions written in articles are under responsibilities of the authors.

The published contents in the articles cannot be used without being cited. 


\title{
The Relationship Among Organizational Commitment and Organizational Citizenship Behavior -A Research Study On Call Center Employees
}

\author{
Eda KILIÇ \\ PHD Student, Uludağ University, Institute of Social Sciences, Labor Economics and \\ Industrial Relations Programme
}

\begin{abstract}
The aim of this study is identified the relationship among organizational commitment, organizational citizenship behavior and their dimensions and the affect of the relationship on call center employees. The questionnaire method has been chosen as data collection. The research population has been consisted of call center employees who worked in the Bursa and Istanbul. In the research sample has been consisted of 251 call center employees who is performing a call center in Bursa and three call centers in Istanbul. The study has two parts. In the first part, the conceptual framework of organizational commitment and organizational citizenship behavior and in the second part, findings and results are ranked as. This research results indicated that a high level positive relation among organizational commitment and organizational citizenship behavior.
\end{abstract}

Keywords: Organizational commitment, organizational citizenship behavior, call center 


\section{Introduction}

Today, human productivity is directly proportional to the efficiency of organizations. After the industrial revolution efficiency as measured by the amount of product, labor that produces the product was being ignored. In modernized societies, technological developments and changes inproductivity in perspective with each passing day, has led to an understanding of the importance of human factors in productivity.

Production was not limited only to the industrial area, has become especially important in service sectors.

This development, increased slightly the importance of the workforce. In particular to ensure customer satisfaction, businesses have become the primary target. To achieve this may be possible by the creation of special units within the institutional structures. For this reason, call centers are very important in terms of customer satisfaction. However, this point emerges the importance of call center employees' satisfaction.

\section{Conceptual Framework}

In call centers, where the rate of staff turnover is so high. The provision of organizational commitment will be effective in ensuring that customer representatives are less affected by the stresses arising from the nature of the work, as it will be later in raising the employee's levels of organizational citizenship behavior.

Parallel to the concept of commitment, which in its most general sense can be defined as obligations which restrict the freedom of an action, organizational commitment is the power of an individual to identify with and commit to a specific organization. (Mowday-Steers-Porter 1979: 226). The psychological commitment felt by an individual for an organization reflects the acceptance by that individual to embrace or absorb the characteristics or perspectives of that organization (O'Reilly-Chatman 1986: 493). Organizational commitment is a psychological state which binds an individual to an organization, and ensures a reduction in potential labour turnover (Allen-Meyer 1990: 14). It is the binding or bonding of an individual to an organization (Mathieu-Zajac 1990: 171).

Among the different approaches to organizational commitment, the prominent approach is that of Meyer and Allen. Firstly, Meyer and Allen proposed that a distinction be made between affective commitment and continuance commitment. Meyer and Allen later suggested that there was a third separate component in the form of normative commitment, which reflects an obligation perceived to retain an individual in an organization. (Meyer et.al. 2002). In the research which they carried out in 1991, Meyer and Allen postulated that organizational commitment has a multidimensional structure made up of three components, namely affective commitment, continuance commitment and normative commitment (Meyer-Irving-Allen 1998).

Affective Commitment: This is defined as an emotional approach to identifying with the organization (Meyer v.dğr. 2002). It is the level of employees' organizational commitment which reflects their emotional attachment and devotion to the organization (Meyer-IrvingAllen 1998). Employees who develop a strong emotional attachment remain within the organization in accordance with their own wishes (Noor-Noor 2006).

Continuance Commitment: This refers to the perception that leaving the organization will be costly (Meyer et.al 2002). Continuance commitment is expected to develop in response to conditions which will increase the cost of leaving (eg. "side bets") (Powell-Meyer 2004). Continuance commitment is the type of organizational commitment which employees develop when they feel the need to remain in the organization due to an absence of alternatives or in order to receive a return on the investments they have made in that organization. 
Normative Commitment: This is believed to develop in response to social pressure. (Meyer et.al. 2002). Normative commitment reflects the feeling of obligation an employee has in order to remain in the organization (Meyer-Irving-Allen 1998). It is the situation in which employees are committed to an organization because they believe that they have to (Noor-Noor 2006).

The term organizational citizenship behavior (OCB), however, was first used when the subject of "extra-role behaviors", first termed by Barnard in the 1930s, was taken up again. Extra-role behavior occurs when employees act voluntarily in favour of an organization without any kind of expectation for themselves. This behavior type is displayed by employees. (Ölçüm Çetin 2004).

The first people to use the term citizenship in literature were Katz and Kahn (Ölçüm Çetin 2004; Y1lmaz-Giderler 2007). According to Katz and Kahn (1977), extra-role behaviors and "supra-role behaviors" facilitate the social flow of organizations and are not directly related to specific job definitions. Examples that may be given of such behaviors are: employees assisting their colleagues, employees' acceptance of new members of staff without any objection, and employees' attempts to reduce conflicts within the organization.

Organ defined OCB as "individual behavior that is discretionary, not directly or explicitly recognized by the formal reward system, and that in the aggregate promotes the effective functioning of the organization" (Kidder-Parks 2001: 942). According to Moorman, Blakely and Niehoff, organizational citizenship behaviors are personal assistance which is important to the progress of work and loyal behaviors displayed by individuals as a result of their devotion to the organization (Yılmaz-Giderler 2007).

OCB has been the subject of a great deal of research. The common conclusion stemming from this research is that $\mathrm{OCB}$ is carried out voluntarily rather than obligatorily. This is the result of a desire to assist one's colleagues or the organization and such persons may be defined as "good soldiers" or "good citizens" (Ölçüm Çetin 2004).

According to Organ, there are three basic features of OCBs. These are (YilmazGiderler 2007);

- OCBs are performed by the employee as a result of personal choice

- OCBs go above and beyond that which is an enforceable requirement of the job description.

- OCBs contribute positively to overall organizational effectiveness.

When approaches to organizational citizenship behavior are examined, although different aspects of OCB are taken up in the studies referred to, the aspects most commonly discussed are those of Organ, Podsakoff and MacKenzie (2006). These aspects are as follows:

Altruism: Discretionary behaviors that have the effect of helping a specific work colleague with an organizationally relevant task or problem.

Conscientiousness: This consists of behaviors that go well beyond the minimum role requirements of the organization.

Courtesy: Forward-looking behaviors displayed by employees which assist colleagues in preventing problems from arising.

Civic Virtue: This refers to behaviors that support the development of the organization.

Sportsmanship: This type of behavior can be defined as a willingness on the part of the employee that signifies the employee's tolerance of less-than-ideal organizational circumstances without complaining.

Moorman, Niehoff and Organ, as a result of their research, established that a significant relationship exists between the affective commitment and continuance 
commitment aspects and OCB (1993). Organ and Ryan studied the relationship between organizational commitment and $\mathrm{OCB}$, and, whilst ascertaining a significant relationship between continuance commitment and compliance, they did not find a significant relationship between affective commitment and either the altruism or compliance aspects (1995). Bolon, in his study, established an effect of the affective commitment aspect on OCB directed toward the individual, but did not find a significant relationship between continuance commitment and normative commitment (1997).

Meyer et al., included organizational citizenship behavior in the three-component model of organizational commitment that they developed. Whilst stating a significant and positive relationship between the affective and normative aspects of organizational commitment and organizational citizenship behavior, they found that continuance commitment had a negative relationship or that there was no relationship at all with OCB (2002).

Bolat and Bolat, in their examination of the relationship between organizational commitment and organizational citizenship behavior in the hotel business, suggested that there were significant relationships between all aspects of organizational commitment and OCB but that among the aspects of organizational commitment, the one achieving the strongest relationship with OCB was that of normative commitment (2008). In his study, Güven concluded that several aspects of organizational commitment had a relationship with aspects of organizational citizenship behavior (2006). According to this study, affective commitment, particularly, results in the development of organizational citizenship behavior. Altınbaş as a result of his study, concluded that the affective and continuance aspects of organizational commitment had relationships with all aspects of organizational citizenship behavior at significant levels (2008).

As can be understood from the researches made, a great number of studies have been carried out on the relationship between organizational citizenship behavior and organizational commitment and it has been established that when one of the state levels of this relationship increases, so will the other one. The relationship that this study examines and attempts to prove is also in this direction.

The aim of this research is to establish the relationship between organizational commitment and organizational citizenship behaviors and their effects on employees in call centres. Moreover, by establishing the effects of these behaviors on employees, it is also intended to be instructive from the viewpoint of continuance and productivity in organizations.

The research hypothese can be predicted as follow.

Hypothese 1: Organizational commitment will be positive related to organizational citizenship behavior.

\section{Methods}

\section{Instruments}

As a means of data-collection for the study, an 18-item organizational commitment scale composed by bringing together the affective commitment scale developed by Meyer and Allen in 1991 and the continuance commitment and normative commitment scales developed in 1993, together with an organizational citizenship scale made up of a total of 24 items with questions taken from the aspects developed by Podsakoff et al.(1990) (5 each from the altruism, conscientiousness, sportsmanship and courtesy aspects and 4 from the civic virtue aspect) were used. The items in the scales are of the 7-point likert type, ranging from "I disagree completely" to "I agree completely". 
Table 1:Reliability Analysis Results for scales

\begin{tabular}{lccccc}
\hline Scales & Items & $\mathrm{N}$ & Mean & s.d & C.Alpha \\
\hline $\begin{array}{l}\text { Organizational } \\
\text { Commitment }\end{array}$ & 16 & 251 & 4,37 & 0,92 & 0,81 \\
OCB & 24 & 251 & 5,08 & 0,96 & 0,90 \\
\hline
\end{tabular}

Table 1 shows that, the 0.81, all coefficients are within acceptable scales have reliability coefficients of 0.90 to limits in the social sciences.

Table 2: Distribution of participants in terms of some demographic variables

\begin{tabular}{|c|c|c|}
\hline Sex & $\mathrm{N}$ & $\%$ \\
\hline Male & 88 & 35,1 \\
\hline Female & 163 & 64,9 \\
\hline Total & 251 & 100,0 \\
\hline Age & $\mathrm{N}$ & $\%$ \\
\hline $18-20$ & 27 & 10,8 \\
\hline $21-26$ & 182 & 72,5 \\
\hline $27+$ & 42 & 16,7 \\
\hline Total & 251 & 100,0 \\
\hline Marital Status & $\mathrm{N}$ & $\%$ \\
\hline Single & 218 & 86,9 \\
\hline Married & 31 & 12,4 \\
\hline Divorced & 2 & 0,7 \\
\hline Total & 251 & 100,0 \\
\hline Education & $\mathrm{N}$ & $\%$ \\
\hline Primary Ed. & 3 & 1,2 \\
\hline High school & 107 & 42,6 \\
\hline University & 141 & 56,2 \\
\hline Total & 251 & 100,0 \\
\hline $\begin{array}{l}\text { Years with the } \\
\text { organization }\end{array}$ & $\mathrm{N}$ & $\%$ \\
\hline $1-6$ months & 113 & 45,0 \\
\hline 7-12 months & 85 & 33,9 \\
\hline 13-18 months & 15 & 6,0 \\
\hline 19-24 months & 26 & 10,3 \\
\hline $25+$ months & 12 & 4,8 \\
\hline Total & 251 & 100,0 \\
\hline Working Years & $\mathrm{N}$ & $\%$ \\
\hline $1-6$ years & 203 & 80,9 \\
\hline 7-12 years & 40 & 15,9 \\
\hline $13+$ years & 8 & 3,2 \\
\hline Total & 251 & 100,0 \\
\hline
\end{tabular}




\section{Participants}

The questionnaire was carried out by delivering the forms to and later collecting them from call centre employees at a call centre of the in-house type serving in Bursa and at three different call centres of the outsource type serving in Istanbul, one section of them being carried out face to face, the other section being given to team leaders. A total of 400 forms were delivered, 100 being given face to face to call centre employees, of which 78 were completed, and of the questionnaires collected, a total of 251 containing valid data were used for evaluation in this study

\section{Results}

$64.9 \%$ of the call centre employees who took part in the study were females. Relying on the fact that most of the employees were of the 21-26 age group, we can conclude that a young workforce is employed in call centres. When looking at the other demographic data, it can be seen that $74.1 \%$ were single and that $55.8 \%$ were university graduates. The fact that $80.9 \%$ of call centre employees had had working lives of 1-6 years indicates an inexperienced workforce. $45 \%$ of the staff had worked in that organization for 1-6 months.

The Relationship Among Organizational Commitment, Organizational Citizenship Behavior and Their Dimensions are shown in Table 3.

Table 3:The Relationship Among Organizational Commitment, Organizational Citizenship Behavior and Their Dimensions

\begin{tabular}{|c|c|c|c|c|c|c|c|c|c|c|}
\hline & Alt. & Cons. & Cour. & Civ.V. & Sport. & OCB & Affec. & Cont. & Norm. & O.Com \\
\hline Alt. & 1 & ** & ** & $* *$ & ** & $* *$ & $* *$ & $* *$ & $* *$ & ** \\
\hline Cons. & $694^{* *}$ & 1 & $* *$ & ** & $* *$ & $* *$ & $* *$ & ** & $* *$ & ** \\
\hline Cour. &, $231^{* *}$ & $180^{* *}$ & 1 & $* *$ & $* *$ & $* *$ & $* *$ & & & $* *$ \\
\hline Civ.V. &, $805^{* *}$ & ,753** & $258^{* *}$ & 1 & $* *$ & $* *$ & $* *$ & $* *$ & $* *$ & $* *$ \\
\hline Sport. & ,790** & ,700** & $194^{* *}$ &, $776^{* *}$ & 1 & $* *$ & $* *$ & $* *$ & $* *$ & $* *$ \\
\hline OCB & $887^{* *}$ & $835^{* *}$ & $483^{* *}$ &, $905^{* *}$ & $859^{* *}$ & 1 & $* *$ & $* *$ & $* *$ & $* *$ \\
\hline Affect. &, $391^{* *}$ &, $338^{* *}$ &, $305^{* *}$ &, $354^{* *}$ &, $383^{* *}$ &, $447^{* *}$ & 1 & $* *$ & $* *$ & $* *$ \\
\hline Cont. & ,289** & $216^{* *}$ &,- 010 &, $215^{* *}$ & $242^{* *}$ & $238^{* *}$ & $341^{* *}$ & 1 & $* *$ & $* *$ \\
\hline Norm. & $401^{* *}$ &, $348^{* *}$ & 101 &, $314^{* *}$ & $368^{* *}$ & $384^{* *}$ &, $592^{* *}$ &, $612^{* *}$ & 1 & $* *$ \\
\hline O.Com &, $441^{* *}$ &, $370^{* *}$ &, $170^{* *}$ &, $362^{* *}$ & $407^{* *}$ & $440^{* *}$ &, $803^{* *}$ &, $765^{* *}$ & $898^{* *}$ & 1 \\
\hline
\end{tabular}

**.Correlation is significant at the 0.01 level (2-tailed)

When examining the relationships between the aspects of organizational commitment and organizational citizenship behavior, it is seen that there is a positive relationship (0.447) between affective commitment and organizational citizenship behavior, a positive but weak relationship $(0.238)$ between continuance commitment and $\mathrm{OCB}$, and also a positive but weak relationship
(0.384) between normative commitment and OCB. When we examine the relationships formed with organizational citizenship behavior, we can observe that of the aspects of organizational commitment, the one having the strongest relationship compared to the others is that of affective commitment. In this case, when affective commitment increases, organizational citizenship behavior will also increase. 
On the other hand, when examining the relationship between the aspects of organizational citizenship behavior and organizational commitment, it can be seen that there is a positive relationship (0.441) between altruism and organizational commitment, a positive relationship (0.370) between conscientiousness and organizational commitment, a positive but weak relationship (0.170) between sportsmanship and organizational commitment, a positive relationship (0.362) between courtesy and organizational commitment, and a positive relationship (0.407) between civic virtue and organizational commitment. Of the aspects of organizational citizenship behavior, the one with the strongest relationship with organizational commitment is that of altruism. According to this, it may be said that organizational commitment increases altruistic behaviors.

When examining the relationships between the aspects of organizational commitment and those of organizational citizenship behavior, it is seen that the organizational citizenship behavior which is most affected by affective commitment (0.391), continuance commitment (0.289) and normative commitment (0.401), is that of altruism. When we examine which aspects of organizational commitment affect the other aspects of organizational citizenship behavior, however, it can be seen that when conscientiousness is displayed, the most influential type of commitment is that of normative commitment (0.348), and that increases in sportsmanship (0.305), courtesy (0.354) and civic virtue (0.383) behavior types are mostly due to the effect of affective commitment. In other words, compared with the other types of commitment, that of affective commitment has the most powerful effect on all aspects of organizational citizenship behavior with the exception of the conscientiousness aspect. The results can be interpreted so as to say that when affective and normative commitment increase, altruistic behavior will also increase, and that when continuance commitment increases, civic virtue behavior will also increase. Because the internalisation of norms exists as the basis for both normative commitment and conscientious behavior, the fact that when normative commitment increases, conscientious behavior also increases, is a significant result.

\section{Discussion}

Call centers has developed in the world the last 50 years, in Turkey in the last 15 years. They provide companies reach customers, ensuring customer satisfaction, customers' problems, requests and complaints access their companies. And this is very important for organization. At the same time call center employees are buffer zone between the company and the customer, and therefore negatively affected.

In addition, call center employees have some problems. These problems are; health problems (hearing loss, diseases of the vocal cords), underemployment, limited career opportunities, short-term breaks, alienation etc.. Therefore call center employees will not be able to develop the behavior of organizational commitment.

In this direction a positive relationship among organizational commitment and organizational citizenship behavior has been proven. First, the demographic variables were investigated. And, correlation analysis were performed to determine the relationship among organizational commitment, organizational citizenship behavior and sub-dimensions.

Employees with low organizational commitment will tend to leave when they find a new job. This situation brings extra cost, especially for organizations, leads to a lose of time and negatively affects productivity. But employees with high organizational commitment like their job, want to continue to working and are satisfied. Organizations should provide organizational commitment and OCB for employers' satisfaction, productivity and continuity. This is very important for both organizations and employers. 


\section{References}

Altınbaş, Burç (2008). Örgütsel Bağlılık ve Örgütsel Vatandaşlık Arasındaki İlişki ve Bir Uygulama, Yıldız Teknik Üniversitesi Sosyal Bilimler Enstitüsü, (Yayımlanmamış Yüksek Lisans Tezi), İstanbul.

Bolat, Oya İ. - Bolat, Tamer (2008). Otel

İşletmelerinde Örgütsel Bağlılık ve Örgütsel Vatandaşlık Davranışı İlişkisi, Balıkesir Üniversitesi Sosyal Bilimler Enstitüsü Dergisi, c. 11, p. 19, Haziran, pp.75-94.

Bolon, Douglas S. (1997). Organizational Citizenship Behavior Among Hospital Employees: A Multidimensional Analysis Involving Job Satisfaction and Organizational Commitment, Hospital \& Health Services Administration, vol. 42, no. 2, Summer, pp. 221-241.

Güven, Murat (2006). Örgütsel Bağlılık Ve Örgütsel Vatandaşlık Davranışı Arasındaki İlişki, Marmara Üniversitesi Sosyal Bilimler Enstitüsü, (Yayımlanmamış Yüksek Lisans Tezi), İstanbul.

Katz, Daniel - Kahn, Robert L. (1977) Örgütlerin Toplumsal Psikolojisi, çev. Halil Can-Yavuz Bayar, Türkiye ve Orta Doğu Amme İdaresi Enstitüsü Yayınları, nu. 167, Ankara.

Kidder, Deborah L. - Parks Judi M. (2001) “The Good Soldier: Who is S(he)?" Journal of Organizational Behavior, vol 22, pp. 939959.

Mathieu, Joron E. - Zajac, Dennis. M. (1990). A Review and Meta-Analysis of the Antecedents, Correlates, and Consequences of Organizational Commitment, Psychological Bulletin, vol. 108, no. 2, pp. 171-194.

Meyer, John P. - Allen Natalie J. (1991) A three component conceptualization of organizational commitment, Human Resource Management Review, vol.1, no. 1, pp. 61-89.

Meyer, John P. - Irving, Gregory P. - Allen, Natalie J. (1998) Examination of the Combined Effects of Work Values and Early Work Experiences on Organizational Commitment, Journal of Organizational Behavior, vol. 19, no. 1, January, pp.29-52.

Meyer, John P. et.al. (2002)“Affective, Continuance, and Normative Commitment to the
Organization: A Meta-analysis of Antecedents, Correlates and Consequences", Journal of Vocational Behavior, vol. 61, no. 1, Agust, pp. 20-52.

Moorman, Robert. H. - Niehoff, Brian. P. - Organ, Dennis. W. (1993). Treating Employees Fairly and Organizational Citizenship Behavior: Sorting the Effects of Job Satisfaction, Organizational Commitment, and Procedural Justice". Employee Responsibilities and Rights Journal, vol. 6 no. 3, pp. 209-225.

Mowday, Richard T. - Steers, Richard M. - Porter, Lyman W.(1979). The Measurement of Organizational Commitment, Journal of Vocational Behavior, no. 14, pp. 224-247.

Noor, Harun A. K. - Noor, Hasrul N. M. (2006). Evaluating The Psychometric Properties Of Allen And Meyer's Organizational Commitment Scale: A Cross Cultural Application Among Malaysian Academic Librarians", Malaysian Journal of Library $\mathcal{E}$ Information Science, vol. 11, no. 1, July, pp. 89-101.

Organ, Dennis W. - Podsakoff, Philip M. - MacKenzie, Scott B. (2006) Organizational Citizenship Behavior: Its Nature, Antecedents, and Consequences, SAGE Publications.

Organ, Dennis W. - Ryan, Katherine (1995). A MetaAnalytic Review of Attitudinal and Dispositional Predictors of Organizational Citizenship Behavior, Personel Psychology, vol. 48 , no. 4, Winter, pp. 775-802.

O'Reilly, Charles - Chatman, Jennifer (1986). Organizational Commitment and Psychological Attachment: The Effects of Compliance, Identification, and Internalization on Prosocial Behavior, Journal of Applied Psychology, no. 71, pp. 492499.

Ölçüm Çetin, Münevver (2004). Örgütsel Vatandaşlık Davranışı, Nobel Yayın Dağıtım, Ankara.

Podsakoff, Philip M. et.al.(1990). Transformational Leader Behaviors and Their Effects on Followers' Trust in Leader, Satisfaction, and Organizational Citizenship Behaviors, Leadership Quarterly, vol. 1, pp. 107-142.

Powell, Deborah M. - Meyer, John P. (2004). Sidebet Theory and the Three-component Model of Organizational Commitment, Journal of 
Vocational Behavior, vol. 65, no. 1, pp. 157177.

Wiener, Yoash (1982). Commitment in Organizations: A Normative View, The Academy of Management Review, vol. 7, no. 3, July, pp. 418-428.

Yılmaz, Abdullah - Giderler, Ceren (2007). Örgütsel Vatandaşlık Davranışı Üzerine Kuramsal Bir İnceleme, EKEV Akademi Dergisi, p. 30, Yil 11, Kış, pp. 263-278. 